Barbara Murawska*, Magdalena Gabrowska*, Ewa Spychaj-Fabisiak*, Elżbieta Wszelaczynska**, Jarosław Chmielewski**

\title{
Production and environmental aspects of the application of biostimulators Asahi SL, Kelpak SL and stimulator Tytanit with limited doses of nitrogen Produkcyjne i środowiskowe aspekty stosowania biostymulatorów Asahi SL i Kelpak SL oraz stymulatora Tytanit przy ograniczonych dawkach azotu
}

*Zakład Chemii Rolnej, Katedra Chemii Środowiska, **Katedra Mikrobiologii i Technologii żywności, Uniwersytet Technologiczno-Przyrodniczy w Bydgoszczy; e-mail:murawska@utp.edu.pl

Keywords: winter wheat, biostimulators, nitrogen fertilization, root mass, chlorophyll content, yield.

Słowa kluczowe: pszenica ozima, biostymulatory, nawożenie azotem, masa korzeni, zawartość chlorofilu, wielkość plonu.

\section{Abstract}

An effective way to reduce nitric oxide emissions may be to reduce the level of nitrogen fertilization. Specialized formulations such as biostimulators are a good alternative to conventional mineral fertilization. The aim of the study was to determine the effect of the application of biostimulation agents (Asahi SL, Kelpak SL, Tytanit) applied against the limited dose of nitrogen $(75 \mathrm{kgN} \cdot \mathrm{ha}-1)$ on winter wheat 'Muszelka', their effect was measured on the parameters: grain yield, protein content, amount of chlorophyll and root mass. No statistically significant changes in yields were observed, but after application of the Asahi SL and Kelpak $\mathrm{SL}$, considerably higher values were found as compared to the controls. It should be emphasised that the applied formulations significantly affected the root mass and chlorophyll content of the leaves. Especially in the case of roots of the plants where the biostimulator Asahi was used in the phase $\mathrm{BBCH} 37$, Kelpak in $\mathrm{BBCH} 23$ and fertilizer Tytanit in $\mathrm{BBCH} 37$. And in the case of chlorophyll objects, where Tytanit was applied in $\mathrm{BBCH} 37$ and 69. In the study, significant correlation was found only between the chlorophyll content and the root mass $(r=0.54)$.

๑) IOŚ-PIB

\section{INTRODUCTION}

Anthropogenic emission of nitrogen compounds causes disturbance in the environment. Ammonia and nitrogen oxides intensify eutrophication and acidification of the environment, and contribute to the greenhouse effect as well [Sapek 2008]. According to a research conducted by the National Centre for Emissions Balancing and Management [2014], Polish agriculture is a significant emitter of $\mathrm{N}_{2} \mathrm{O}$ (81.27 thousand tons). Consequently, the possibility of reducing the emission of this gas from agricultural sources, mainly from cultivated soils, should be sought. An effective way to reduce $\mathrm{N}_{2} \mathrm{O}$ emissions may be to reduce nitrogen fertilization [Kaiser and Ruser 2000, Jungkunst et al. 2006]. According to the literature data, the measurable effect of $\mathrm{N}_{2} \mathrm{O}$ emission from agricultural soils can only occur

\section{Streszczenie}

Skutecznym sposobem ograniczenia emisji tlenku azotu może być zmniejszenie poziomu nawożenia azotem, w związku z tym stosowanie specjalistycznych preparatów, takich jak biostymulatory, które stanowią dobrą alternatywę dla konwencjonalnego nawożenia mineralnego. Celem badań było określenie wpływu aplikacji preparatów biostymulujących (Asahi SL, Kelpak SL, Tytanit) zastosowanych na tle ograniczonej dawki azotu (75 kgN·ha-1) na wielkość plonu, zawartość białka ziarna pszenicy ozimej odmiany „Muszelka” oraz ilości chlorofilu i masy korzeniowej. W przeprowadzonych badaniach nie zostały potwierdzone zmiany statystyczne plonu, jednak znaczne wyższe jego wartości stwierdzono po aplikacji biostymulatorów Asahi SL oraz Klepak SL w porównaniu do kontroli. Należy podkreślić, że zastosowane preparaty wpływały istotnie na wyraźny wzrost zawartość masy korzeni oraz chlorofilu w liściach, dotyczyło to w przypadku korzeni: obiektów gdzie zastosowano biostymulator Asahi w fazie $\mathrm{BBCH} 37$, Klepak w fazie 23 i nawóz Tytanit w fazie BBCH 37,a w przypadku chlorofilu obiektów gdzie aplikowano Tytanit w fazach BBCH 37 i 69. Stwierdzono istotne dodatnią korelacje jedynie pomiędzy pomiędzy zawartością chlorofilu a masą korzeni $(r=0,54)$.

when nitrogen doses are reduced, and soil treatment is regulated [Sosulski et al. 2015]. This can also happen by using products such as biostimulators (growth stimulators or phytostimulators). The intensification of agricultural production has adversely affected the fertility of the soil and thus, the environment. In addition, adverse biotic and abiotic conditions in crops can cause stressful reactions in plants, which can adversely affect their productivity. As a result, farmers increasingly seek safe and natural methods to improve soil productivity, and protect it from degradation. In modern cereal cultivation technology, the application of biostimulators has become a common practice in Poland. Their rational use is currently one of the main factors of the environment and soil productivity. As past researches have 
Table 1. Scheme of experience of wheat variety 'Muszelka' — dose and development phase in which the formulations were applied.

\begin{tabular}{|c|c|c|c|c|}
\hline Object- objekt & Agent- preparat & Rate- dawka & Developmental phase- faza rozwoju & $\begin{array}{c}\text { BBCH phase- Skala } \\
\text { Zadoksa }\end{array}$ \\
\hline 1 & Kontrola '0' & & '0' & BBCH 23 \\
\hline 2 & Tytanit (T1) & 0,2 ha-1 $^{-1}$ & tillering- krzewienie & BBCH 37 \\
\hline 3 & Tytanit (T2) & $0,2+0,21 \cdot \mathrm{ha}^{-1}$ & stem elongation- strzelanie w źdźbło & BBCH 69 \\
\hline 5 & Tytanit (T3) & $0,2+0,2+0,21 \cdot$ ha $^{-1}$ & end of flowering- po kwitnieniu & BBCH 23 \\
\hline 6 & Asahi SL (A1) & $0,61 \cdot$ ha $^{-1}$ & tillering- krzewienie & BBCH 37 \\
\hline 7 & Asahi SL (A2) & $0,6+0,61 \cdot \mathrm{ha}^{-1}$ & stem elongation- strzelanie w źdźbło & BBCH 23 \\
\hline
\end{tabular}

shown, their task is to accelerate and control life processes and to increase plant resistance to stress.

These stimulators are safe for the environment and can in part complement the activity of chemical means of plant production including fertilization. Biostimulators are biologically active substances and are manufactured from the extracts from marine organisms (algae and seaweed), microorganisms, phytohormones and micro- and macroelements (e.g., titanium). In order to increase the production, potential biostimulators activate the metabolism and chemical reactions throughout the plant. Their main task is to improve the quantitative and qualitative parameters of crops as well as the amount of chlorophyll and root mass, which supports the uptake of nutrients from the soil, and thereby affects the reduction of their losses from the soil environment, in particular nitrogen [Jankowski and Dubis 2008, Kozak et al. 2008, Matysiak et al. 2011, Pacholczak et al. 2013, Jankowski et al. 2014]. In light of the current research and agricultural practice, it has been proven that the use of supporting preparations helps to minimize intensive mineral fertilization, in particular the doses of nitrogen. The aim of the study was to determine the effect of the application of biostimulation agents (Asahi SL, Kelpak SL, Tytanit) applied against the limited dose of nitrogen $(75 \mathrm{kgN} \cdot \mathrm{ha}-1)$ on winter wheat 'Muszelka'. Measuring grain yield, protein content, amount of chlorophyll and root mass.

\section{MATERIAL AND METHODS}

The source material includes the results from the field experiments conducted in the years 2014-2015 at the Research Station of the Faculty of Agriculture and Biotechnology in Mochelek, the University of Technology and Life Sciences. The experiments were carried out on the luvisols, which are classified as Class IVa - average quality arable soil. This region is characterized by average air temperatures of $7.7^{\circ} \mathrm{C}$ and mean of summer months (IV-IX) is $14^{\circ} \mathrm{C}$, while the average annual precipitation is low and is $432 \mathrm{~mm}$.

The study was conducted on the basis of a one-factorial field experiment, where three stimulating agents were applied in different doses and developmental phases. Depending on the formulation (BBCH 23, 37, 69) and the control $(n=7)$, against the limited mineral fertilization. The following stimulant agents were used: Tytanit - mineral fertilizer, also classified as mineral growth stimulants; Asahi SL — plant growth and yield stimulator, biostimulant based on three nitrophenols; Kelpak SL — growth regulator, algae extract containing plant hormones: auxins, cytokines.

The test plant was winter wheat variety 'Muszelka', which is characterized by excellent prolificacy, for which the forecrop was winter oilseed rape. Wheat was sown on 24.09.2014 in the amount of $280 \mathrm{~kg} \cdot \mathrm{ha}^{-1}$. Harvest was made at full maturity of grain in the second decade of July. Fertilization of NPK was applied on all objects including control at the following doses: $75 \mathrm{~kg} \mathrm{~N} \cdot \mathrm{ha}^{-1}\left(20 \mathrm{~kg} \cdot \mathrm{ha}^{-1}\right.$ in autumn, $50 \mathrm{~kg} \cdot \mathrm{ha}^{-1}$ in spring in the form of ammonium nitrate and $5 \mathrm{~kg} \cdot \mathrm{ha}^{-1}$ in the form of urea for leaf sprays), $30 \mathrm{~kg} \mathrm{P} \cdot \mathrm{ha}^{-1}$ and $66 \mathrm{~kg} \mathrm{~K} \cdot \mathrm{ha}^{-1}$. The cultivation of wheat has been done according to the rules of proper agricultural technology recommended for this plant.

During the vegetation period, following measurements were taken on the representative plants under the effect of stimulant: content of chlorophyll in leaves and root weight of wheat. These studies were conducted two weeks after the application of biostimulants used in particular phases of phenological development. The harvest of winter wheat 'Muszelka' yield from each plot was made in the second decade of July in the full maturity of grain $(\mathrm{BBCH}$ 89).

The representative samples of plant material were collected, and following parameters were determined: total protein content in grain using whole grain analyser Infratec 1241; chlorophyll content in leaves using a Minolta-type apparatus. The individual parameters were determined according to the applicable standards for specialized devices with international ICC standards.

The results obtained were statistically analysed by one-way analysis of variance according to a model compatible with the experience system, evaluating the significance of differences in the Tukey test with the significance level $\alpha=0.05$, and calculating the correlation between the tested parameters using Statistica 10.0.

\section{RESULTS AND DISCUSSION}

It was found that the stimulants used in the study significantly increased the protein content in grain of winter wheat, as well as the amount of chlorophyll and the root mass, but did not significantly differentiate the yield (Table 2).

Despite the lack of significant influence on the yield of winter wheat 'Muszelka', after applying the agents in different phenological 
Table 2. Mean values of selected winter wheat grain parameters from two years of research (2014-2015), depending on the application of stimulants against fertilization.

\begin{tabular}{|c|c|c|c|c|c|c|}
\hline \multicolumn{7}{|c|}{ Fertilization variants - warianty nawozowe } \\
\hline „0" & T1 & T2 & T3 & A1 & A2 & $\mathbf{K}$ \\
\hline \multicolumn{7}{|c|}{ Yield - plon [t·ha- $\left.{ }^{-1}\right]$} \\
\hline $4,82^{\text {n.i. }}$ & $5,35^{\text {n.i. }}$ & $4,81^{\text {n.i. }}$ & $4,81^{\text {n.i. }}$ & $5,21^{\text {ni. }}$ & $5,6^{\text {n.i. }}$ & $5,55^{\text {n.i. }}$ \\
\hline \multicolumn{7}{|c|}{ Protein content - zawartość białka ogólnego $\left[\mathrm{g} \cdot \mathrm{kg}^{-1}\right]$} \\
\hline $118,8^{\mathrm{a}}$ & $123^{\mathrm{a}}$ & $126,5^{\mathrm{ab}}$ & $120^{\mathrm{a}}$ & $126,5^{\mathrm{ab}}$ & $119,2^{\mathrm{a}}$ & $116,2^{\mathrm{a}}$ \\
\hline \multicolumn{7}{|c|}{ Weight of roots - masa korzeni [g] } \\
\hline $4,74^{\mathrm{a}}$ & $6,03^{\mathrm{b}}$ & $10,27^{\text {ba }}$ & $12,35^{\mathrm{abc}}$ & $6,52^{\mathrm{abc}}$ & $12,19^{\mathrm{abc}}$ & $12,5^{\mathrm{abc}}$ \\
\hline \multicolumn{7}{|c|}{ Chlorophyll content - zawartość chlorofilu [SPAD] } \\
\hline $553,33^{a}$ & $574,5^{b}$ & $619^{\mathrm{abcd}}$ & $627,67^{\text {abcd }}$ & $563,33^{a}$ & $593,5^{\mathrm{abc}}$ & $585,17^{\mathrm{ab}}$ \\
\hline \multicolumn{7}{|c|}{$\begin{array}{l}\text { '0'- control- kontrola; } \\
\text { The application of a stimulant- zastosowanie preparatu: T1- Tytanit used in the stage BBCH 23, T2- Tytanit used in the stage } \\
\text { BBCH 37, T3- Tytanit used in the stage BBCH } 69, \mathrm{~A} 1 \text { - Asahi SL used in the stage BBCH 23, A2- Asahi SL used in the stage BB } \\
37, \mathrm{~K}-\text { Kelpak SL used in the stage 23; } \\
\text { n.i.- non-significant differences- różnice nieistotne; } \\
\text { a, b, ... - mean values marked with different letters in line differ significantly depending on the fertilization variants; } \\
\text { a, b, ... - wartości średnie oznaczone różnymi literami w wierszu różnią się istotnie w zależności od zastosowanych wariantów } \\
\text { nawozowych. }\end{array}$} \\
\hline
\end{tabular}

phases against mineral fertilization, its size was varied and ranged from $4.81 \mathrm{t} \cdot \mathrm{ha}^{-1}$ to $5.6 \mathrm{t} \cdot \mathrm{ha}^{-1}$, with an average of $5.16 \mathrm{t} \cdot \mathrm{ha}^{-1}$. The highest average yield from years of study was obtained at the object where biostimulant Asahi SL was applied in phase $\mathrm{BBCH}$ 37 , and the lowest after application of Tytanit in phase $\mathrm{BBCH} 37$ and 69 (Table 2). However, it should be noted that the average grain yield after the application of Asahi SL (BBCH 37), Kelpak $\mathrm{SL}$ (BBCH 23) Tytanit (BBCH 23) and Asahi SL (BBCH 23) were higher compared to the control by $16 \%, 15 \%, 11 \%$ and $8 \%$, respectively (Figure 1). Consequently, it can be considered that the biostimulants used against limited nitrogen dose produced higher or comparable yields, irrespective of the time of their application compared to the yields obtained from control crops. This confirms the hypothesis that the reduction of the nitrogen dose, together with the application of the formulation, does not affect the grain yield and in some cases, may even contribute to their increase. The influence of biostimulators on wheat grain yields was also obtained by other authors in their research [Kozak et al. 2008, Kotwica et al. 2014, Kierzek et al. 2015]. Accordingly, the combined use of a limited dose of nitrogen $\left(75 \mathrm{~kg} \mathrm{~N} \cdot \mathrm{ha}^{-1}\right)$ and biostimulant agents resulted in higher yields compared to the cited literature (80-160 kg N·ha-1) [Truba et al. 2012, Knapowski et al. 2016] and this causes a higher intake of nutrients from the soil.

The used agents significantly impacted the total protein content in winter wheat grains, which was within the range of $116.2 \mathrm{~g} \mathrm{~kg}^{-1}$ to $126.5 \mathrm{~g} \cdot \mathrm{kg}^{-1}$, with an average content of $121.45 \mathrm{~g} \cdot \mathrm{kg}^{-1}$ (tab. 2). The results obtained are consistent with those reported in the literature for winter wheat, and are within the range of 90 to 130 $\mathrm{g} \mathrm{kg}^{-1}$ [Wróbel, Woźniak 2008, Knapowski et al. 2010].

After the application of the tested stimulant agents, there was generally a significant increase in the mean total protein content

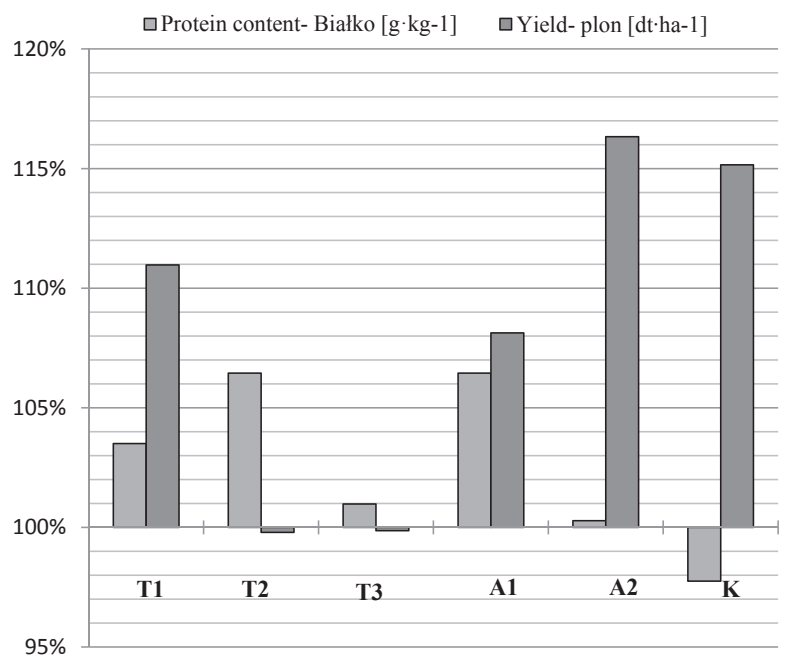

for explanations, see Table 2 - objaśnienia pod tabelą 2

Figure 1. Protein content and yield of winter wheat variety 'Muszelka' after application of the tested agents depending on the time of their use by $\mathrm{BBCH}$ scale, (as $100 \%$ - control).

in grain of winter wheat compared to the value obtained on the control object, except the object where Kelpak SL was applied. The highest content of this parameter was obtained after the application of Asahi SL in $\mathrm{BBCH} 23$ and Tytanit in stage $\mathrm{BBCH}$ 37 ; they were significantly higher by $6.5 \%$ compared to the control. The higher values of total protein content in wheat grains collected from the facilities, where these biostimulators were applied may indicate that they have a significant effect on the higher nitrogen uptake from the soil and on its proper metabolism in the plant. These results confirm the thesis by Czubiński [2011] that states the biostimulating agents are substances that affect 
the changes in biochemical processes in the plant, increase the natural reactions in plant cells. Also, Kowalska et al. [2012] confirms that they increase the intensity of nutrient uptake by crops by improving the existing mechanisms in plants.

The biostimulators significantly determined the amount of chlorophyll in wheat leaves, which was examined two weeks after the application of stimulators used within phenological phases. It has been found that the amount of chlorophyll increased for all the agents used in relation to control (Table 2). Significant increase in the amount of chlorophyll only by $3 \%$ occurred after the application of Tytanit in phase BBCH 23. However, in the phases $\mathrm{BBCH} 37$ and $\mathrm{BBCH} 69$, the amount of chlorophyll increased by $12 \%$ and $13 \%$ respectively (Figure 2), which did not respond with the grain yield (Table 2). A similar effect on the amount of chlorophyll in leaves, but slightly smaller, was found in case of Asahi SL, where growth was observed after the application in $\mathrm{BBCH} 23$ only by $2 \%$, but in phase $\mathrm{BBCH} 37$ by up to $7 \%$, compared to control. Where the stimulator Kelpak $\mathrm{SL}$ was applied in $\mathrm{BBCH} 23$, the amount of chlorophyll was $6 \%$ higher compared to the control (Table 2.). It can be concluded that the single application of the Kelpak SL in phase $\mathrm{BBCH} 23$ was most effective for the amount of chlorophyll in this phase, also compared to all tested biostimulation agents (Figure 2). It should be noted that the other two stimulators: Tytanit and Asahi $\mathrm{SL}$, applied in the following phases, significantly affected the increase in the amount of chlorophyll content obtained after the phase $\mathrm{BBCH} 23$ compared to the control.

Similar results were obtained by Thirumaran et al. [2009] and Matysiak et al. [2012], showing the effect of Ecklonia maxima algae on chlorophyll content. Also, the positive effect of biostimulants on the content of the chlorophyll in the leaves of plants was found by Przybysz et al. [2008] and by Joubert and Lefranc [2008].

The root mass of the winter wheat 'Muszelka', determined on the basis of representative samples, was characterized by a significant increase and ranged from $4.74 \mathrm{~g}$ to $12.5 \mathrm{~g}$. The onetime application of the Kelpak SL increased the tested parameter by $164 \%$ compared to the control (Figure 2). The three-time application of Tytanit in the studied phenological phases $(\mathrm{BBCH}$ 23, 37 and 69) showed a significant increase in the root mass by $27 \%, 116.6 \%$ and $160.5 \%$ respectively, as compared to the control. While the double use of Asahi SL in $\mathrm{BBCH} 23$ and $\mathrm{BBCH} 37$ increased the weight of the roots of wheat respectively by $37.5 \%$, and $157 \%$ (Table 2). In summary, the application of biostimulators with a reduced dose of nitrogen increased the mass of roots almost 2 or 3 times (Figure 2). Literature sources does not provide conclusive opinion about impact of biostimulators on root mass. For example, Szymczak - Nowak [2009] has a beneficial effect of algae preparations on the increase in root mass, which was confirmed in our study. In contrast, Kołodziej [2004] did not find any increase in root mass after using stimulants.

The correlation values for the parameters studied in winter wheat were also calculated. The significantly positive correlation was found only between the mass of roots and the amount of chlorophyll in leaves $(r=0.54)$. For this relationship, linear regression equations were calculated and presented graphically

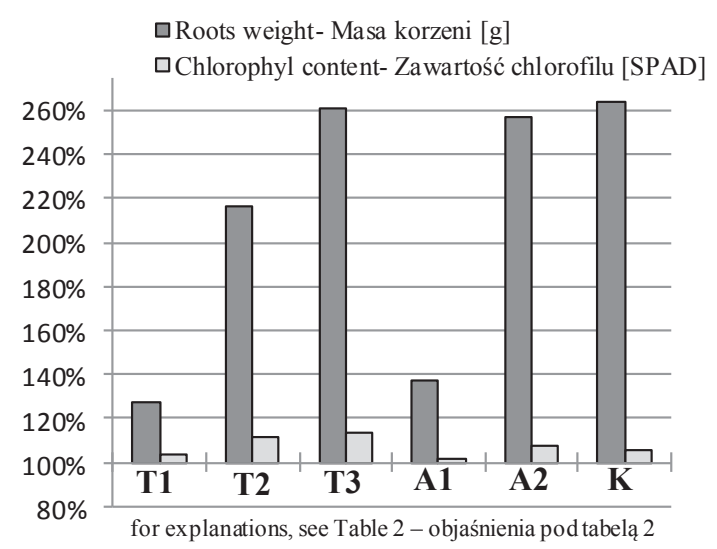

Figure 2. Content of root mass and chlorophyll in leaf of winter wheat 'Muszelka' after the application of the tested agents depending on the time of their use by $\mathrm{BBCH}$ scale, (as $100 \%$ - control).

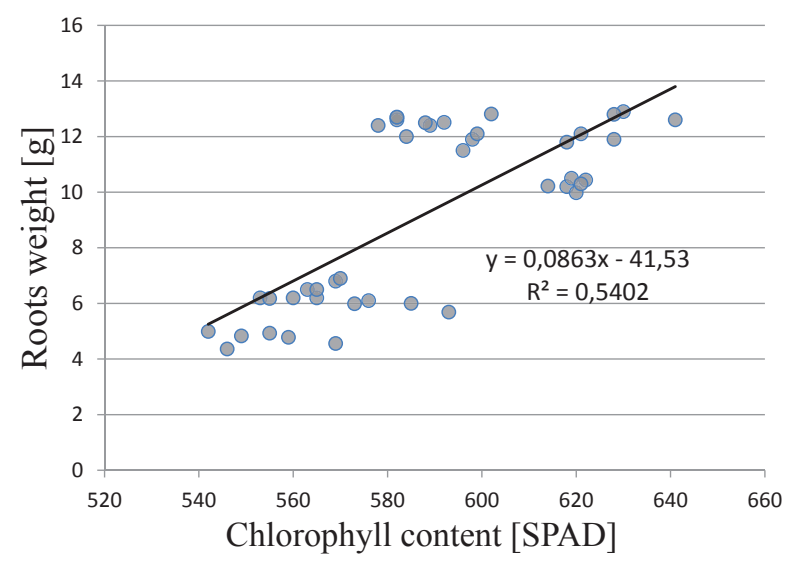

Figure 3. Correlation between root mass [g] and chlorophyll content [SPAD] in winter wheat.

(fig.3), indicating that with increasing root mass chlorophyll content increases. Also, Ibragimova et al. [2008] and Grzyś [2012] in their research showed a significant positive correlation between these parameters after the application of biostimulators. From a number of scientific studies and from the information obtained from the manufacturers, it is clear that the use of biostimulators has a positive effect on the size and quality of the crop and on the growth of the root system. Therefore, on the efficient extraction of nutrients from the soil [Kołodziej 2004, Ibragimova et al. 2008, Kotwica et al. 2014], the application of these stimulators also affects the activity of soil microorganisms, which affects the better use of soil and fertilizer nitrogen. It should be emphasized that the nitrogen not collected by crop plants or soil microorganisms is subject to many processes, as a result of which, a significant part is losses by emission and leaching. This may also lead to the disturbance of microbiological balance and, consequently to soil degradation [Sosnowski et al. 2012].

These studies have shown that the use of biostimulation agents in the era of intensive cultivation of plants may be an effective way to reduce the use of chemicals (fertilization), including the reduction of nitrogen doses. 


\section{CONCLUSIONS}

1. It was found that the applied biostimulation formulas Asahi SL, Kelpak SL and Tytanit, against the reduced dose of nitrogen $\left(75 \mathrm{kgN} \cdot \mathrm{ha}^{-1}\right)$, did not significantly differentiate the grain yield of winter wheat 'Muszelka'. The highest, but statistically unproven, yields were observed after the application of Asahi SL in phase $\mathrm{BBCH} 37$ and Kelpak in phase $\mathrm{BBCH} 23$.

2. The used stimulators significantly differentiated the amount of chlorophyll in wheat leaves and the root mass, their application in the tested phenotypic phases in scale $\mathrm{BBCH}$ influenced the increase of these parameters relative to the control. The highest values were found for chlorophyll after the application of Tytanit in the phase $\mathrm{BBCH} 69$, and in the case of root mass after the application of stimulator Kelpak in $\mathrm{BBCH} 23$.

\section{REFERENCES}

CZUBIŃSKI T. 2011. Stymulatory, aktywatory..., O co w tym chodzi?. Top Agrar Polska 4: 140-143,

GRZYŚ E. 2012. Wpływ wybranych substancji biologicznie czynnych na kukurydzę uprawianą w warunkach stresu. UWP Wrocław, Monografie CXLV.

IBRAGIMOVAA.S., BASYGARAYEV Z.M., KERIMKULOVAA.R., BUKENOVA E.A., GILMANOV M.K. 2008. The new effective biostimulator for agroecological engineering. International Journal of Biological, Biomolecular, Agricultural, Food and Biotechnological Engineering Vol. 2 (8): 171-175.

JANKOWSKI K., DUBIS B. 2008. Biostymulatory w polowej produkcji roślinnej, Biostymulatory w nowoczesnej uprawie roślin. Publikator Wieś Jutra.

JANKOWSKI K., SOSNOWSKI J., WILK A., MALINOWSKA E., WIŚNIEWSKA-KADŻAJAN B. 2014. Effect of growth regulators on selected morphological features of yellow pine. Journal of Ecological Engineering, Vol. 15 (4): 105-108.

JOUBERT J.M., LEFRANC G. 2008. Seaweed phytostimulants in agriculture: recent studies on mode of action two types of products from algae: growth and nutrition stimulants and stimulants of plant defense reactions. Book of abstracts: Biostimulators in modern agriculture. Warsaw, 7-8 February 16.

JUNGKUNST H.F., FREIBAUER A., NEUFELDT H., BARETH G. 2006. Nitrous oxide emissions from agricultural land use in German - a synthesis of available annual field data. Journal of Plant Nutrition and Soil Science, 169 (3): 341-351.

KAISER E.A., RUSER R. 2000. Nitrous oxide emission from arable soils in Germany - An evaluation of six long-term field experiments. Journal of Plant Nutrition and Soil Science, 163: 249-260.

KIERZEK R., DUBAS M., MATYSIAK K. 2015. Effect of biostimulator Aminoplant mixtures with terbuthylazine and bromoxynil (Zeagran 340 SE) on herbicidal effect and yield of maize. Progress In Plant Protection 55 (2): 165-169.

Krajowy raport inwentaryzacyjny, 2014. Inwentaryzacja gazów cieplarnianych w Polsce dla lat 1988-2012. Raport wykonany
3. Total protein content in wheat was significantly increased by the applied biostimulants, the highest average content found after the application of Asahi SL in phase $\mathrm{BBCH} 37$ and Tytanit in $\mathrm{BBCH} 23$, and the lowest was obtained on the control.

4. The study leads to the conclusion that the use of biostimulants against the limited dose of nitrogen appears to be ecologically beneficial. Most of all, they affect the stabilization of yield, the quality of plants, the amount of chlorophyll, the mass of roots and thus a higher download of nitrogen. It can be assumed that these stimulants can contribute to the reduction of nitrogen oxide emissions from agricultural soils.

na potrzeby Ramowej konwencji Narodów Zjednoczonych w sprawie zmian klimatu oraz Protokołu z Kioto. Krajowy Ośrodek Bilansowania i Zarządzania Emisjami. KOBIZE. Warszawa, Maj 2014: 373 pp.

KNAPOWSKI T., KOZERA W., CHMIELEWSKI J., GORCZYCA D., WSZELACZYŃSKA E., POBEREŻNY J. 2016. Mineral fertilization as a factor determining technological value of grain of Triticum aestivum ssp. spelta L.. Ochrona środowiska i zasobów naturalnych VOL. 27 NO 3(69): 8-13.

KNAPOWSKI T., RALCEWICZ M., SPYCHAJ-FABISIAK E., LOŽEK O. 2010. Ocena jakości ziarna pszenicy ozimej uprawianej w warunkach zróżnicowanego nawożenia azotem. FRAGM. AGRON. 27(1): 73-80.

KOŁODZIEJ B. 2004: Wpływ Atoniku oraz nawożenia dolistnego na plonowanie i jakość surowca żeń-szenia amerykańskiego (Panax quinquefolium L.). Annales UMCS, Sec. E, 59, (1): 157-162.

KOTWICA K., JASKULSKA I., GAŁEZEWSKI L., JASKULSKI D., LAMPARSKI R. 2014. Spring wheat yield in short-term monoculture depending on the tillage method, use of organic matter and a biostimulant. Acta Sci. Pol., Agricultura 13(2), 19-28.

KOWALSKAJ., GOLKAW., PTASZYŃSKIS. 2012. Uwarunkowania legislacyjne dotyczące środków wspomagających uprawę roślin i wymagania techniczne ich aplikacji. PIR(IV-VI) z 2 (76).

KOZAK M., MALARZ W., KOTECKI A., ČERNÝ I., SERAFINANDRZEJEWSKA M. 2008. Wpływ zróżnicowanej ilości wysiewu i biostymulatora Asahi SL na skład chemiczny nasion i resztek pozbiorowych soi uprawnej. Rośliny oleiste-Oilseed crops, TOM 29.

MATYSIAK K., ADAMCZEWSKI K., KACZMAREK S. 2011. Wpływ biostymulatora Asahi SL na plonowanie i wybrane cechy ilościowe i jakościowe niektórych roślin rolniczych uprawianych w warunkach wielkopolski. Prog. Plant Prot./ Post. Ochr. Roślin. 51 (4).

MATYSIAK K., KACZMAREK S., KIERZEK R. 2012. Wpływ wyciągu $z$ alg morskich Ecklonia maxima (Kelpak SL) na 
rośliny rzepaku ozimego. Rośliny oleiste - Oilseed crops, TOM 33, 81-88.

PACHOLCZAK A., SZYDŁO W., PETELEWICZ P., SZULCZYK K. 2013. The effect of AminoPlant on rhizogenesis in stem cuttings of Physocarpus opulifolius 'Dart's Gold' and 'Red Baron'. Acta Sci.Pol. Hortorum Cultus, 12 (3), 12.

PRZYBYSZ A., MAŁECKA-PRZYBYSZ M., SŁOWIŃSKI A., GAWROŃSKA H. 2008. The effect of Asahi SL on growth, efficiency of photosynthetic apparatus and yield of field grown oilseed rape. Biostimulators in modern agriculture: Field crops, 7-17.

SAPEK A. 2008. Emisja tlenków azotu (NOx) z gleb uprawnych i ekosystemów naturalnych do atmosfery. Woda-ŚrodowiskoObszary Wiejskie, TOM 8, 1 (22): 283-304.

SOSNOWSKI J, JANKOWSKI K, CIEPIELA G. A, WIŚNIEWSKAKADŻAJAN B, DESKA J. 2012.Wpływ biostymulatora i zróżnicowanego nawożenia azotem na stosunki ilościowe mikroflory glebowej, Inżynieria Ekologiczna Nr 31, 110-118.

SOSULSKI T., SZARA E., STĘPIEŃ W., RUTKOWSKA, B. 2015, The influence of mineral fertilization and legumes cultivation on the N2O soil emissions. Plant Soil Environments, 61: 529536.
SOSULSKI T., SZARA E., STĘPIEŃ W., SZYMAŃSKA M. 2014. Nitrous oxide emissions from the soil under different fertilization systems on a long-term experiment. Plant Soil and Environment, 60: 481-488.

SZYMCZAK-NOWAK J. 2009: Wpływ biostymulatorów na zdrowotność i plonowanie buraka cukrowego. Postępy w Ochronie Roślin 49 (4): 2031-2037

THIRUMARAN G., ARUMUGAM M., ARUMUGAM R., ANANTHARAMAN P. 2009. Effect of seaweed liquid fertilizer on growth and pigment concentration of Abelmoschus esculentus (L.) medicus. American-Eurasian Journal of Agronomy 2 (2): 57-66.

TRUBA M., JANKOWSKI K., SOSNOWSKI J. 2012. Reakcja roślin na stosowanie preparatów biologicznych. The plants reaction on biological preparations treatment $53,41-52$

WRÓBEL J., WOŹNIAKA. 2008. The effect of Atonik plant growth stimulator, applied by different methods, on the physiological activity and yield of common osier (Salix viminalis L.). Book of abstracts of Conference: Biostimulators in modern agriculture, 7-8 February, Warsaw, Poland, 86. 